\title{
Conceptual principles for activation of intensification processes at the mechanical engineering enterprises
}

\author{
V. M. Marchenko, N. M. Pokrovskaya* \\ National Technical University of Ukraine "Igor Sikorsky Kyiv Polytechnic Institute" \\ *Corresponding author. E-mail: n.pokrovski@gmail.com
}

Paper received 24.11.17; Revised 29.11.17; Accepted for publication 30.11.17.

https://doi.org/10.31174/SEND-HS2017-147V25-02

\begin{abstract}
This paper studies the intensification, which is regarded as a set of intensification processes having hierarchical (logical) subordination. The structural model of the activation concept for intensification processes and the algorithm for its application are developed. The golden rule of intensification for the mechanical engineering enterprises is proposed and its essence is revealed.

Keywords: intensification, activation of intensification processes, internal environment, external environment, golden rule of intensification.
\end{abstract}

Introduction. At the stage of significant market transformations, it is impossible to accelerate the growth of a country's industrial potential without searching for sustainable sources for development and activation of the intensification process. In addition, the urgency of the transition to an intensive way of economic management can be explained by the fact that during the years of economic decline the intensification issues were not given proper importance. Today, favorable conditions have emerged for accelerating the pace of intensification by bringing all available potential into the production and its more efficient use that will enable the industrial enterprises to strengthen their competitive position significantly in the European and world markets.

The intensification process is a material basis for the economic growth of the mechanical engineering sector, which, in turn, results in technological modernization of the country; it is a basis for the creation of high-tech science-intensive products, a prerequisite for the growth of an industrial potential in general and a level of social development in particular.

A brief overview of publications on the issue. Intensive development of the industrial enterprises associated with identification of the mechanisms, factors, and trends of the intensification processes were studied by domestic and foreign scientist, including V.V. Sharko, O. Yemelianov, T. Petrushka, L.V. Pogorelova, O. Popova, O.O. Falchenko, O.I. Engels, K.V. Pavlov, I.V. Mitrofanova, A.V. Andreiev and others, who paid much attention to these urgent issues in their works. Despite a rather significant range of scientific works, the issue on systematization of the directions of production intensification requires in-depth study.

The main purpose of the paper is to develop the theoretical principles of the economics further in terms of development of the economic essence of the concepts of intensification and to develop the methodological principles for its evaluation and practical activation at the mechanical engineering enterprises.

Materials and Methods. The scientific works, a set of methods of generalization, analysis and synthesis form the methodological basis for the research.

Results and Discussion. Sustainable development of the enterprise depends on how intensively it uses the available resources, applies new equipment, develops the human potential, that in turn determines the competitiveness of the mechanical engineering products in world markets.
Development and practical implementation of the concept of activation of intensification processes (AIP concept) should become one of the main factors in developing a competitive mechanical engineering complex.

Intensification is one of the main economic categories of a market economy, which characterizes the quality of economic processes of a business entity (industry or enterprise). Today we can state that the concept of intensification has gone beyond the scope of the assessment to what extent the enterprise uses the resources and that it has extended to the assessment to what extent all economic processes are implemented. On this ground, we propose to expand the economic terminological apparatus by supplementing the existing system of concepts related to intensification with such concepts as intensification of the use of resources (as a process of increasing the intensity of the use of human and machine labour; intensification of the production process (as a process of improving the quality level of resource and technology reproduction); intensification of activities (as a process of qualitative changes of all functional modules of the enterprise and increasing the intensity of their use); intensification of development (as a process of transiting the enterprise to a qualitatively higher level by applying the achievements of the scientific and technological progress, resource-saving technologies, progressive methods of labour and enterprises management, a clustered approach to the organization of production process in order to increase the competitiveness of the products).

Therefore, intensification may be regarded as a set of intensification processes having hierarchical (logical) subordination: intensification of the use of resources intensification of production process - intensification of activities - intensification of development. The principle of hierarchy and multilevel nature of intensification processes provides for interdependence and subordination of a lower level of hierarchy to an upper one. Intensification reflects the relationship between resources and objectives of an enterprise at each level.

In the conditions of instability, uncertainty, and dynamism of the economic environment, the mechanism of sustainable development of an enterprise is based on the activation of intensification processes with regard to the goal and with the focus on the final result.

The structural model of the AIP concept is presented in Fig. 1. 


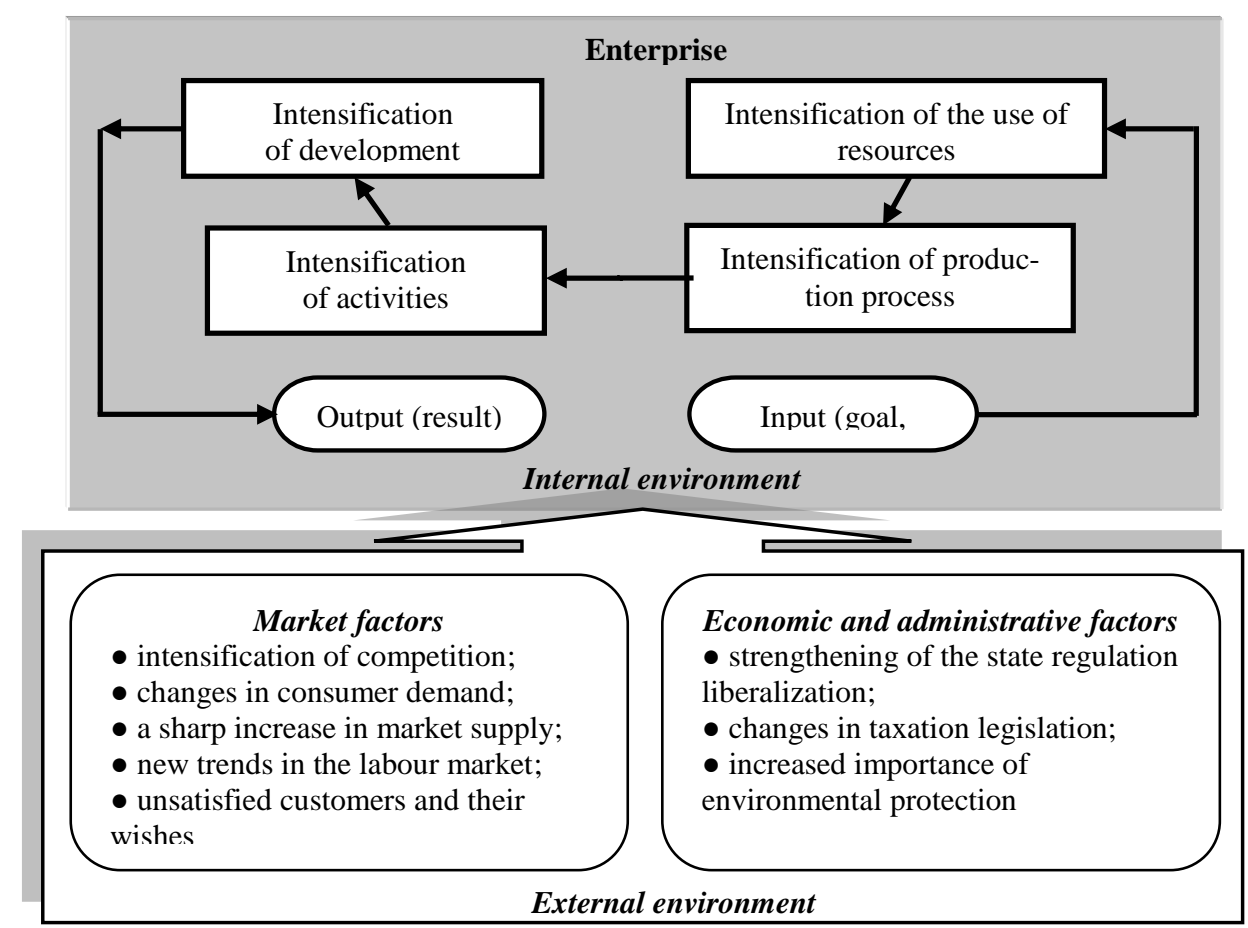

Fig. 1. Structural model of the concept of activation of intensification processes for the mechanical engineering enterprises Source: compiled based on [1-3].

The activation of intensification processes depends on the factors of the internal and external environment of an enterprise. The diversity of the enterprise's internal environment includes the specifics of production, a level of applied technology and equipment at the enterprise, manufacturing process and labour management, financial standing, reproduction of specific types of resources and their structure [1]. Thus, the factors of the internal environment influence the work of the main functional modules of the enterprise: production and technology, resources, finances, marketing and management, innovations and investments.

The external environment factors affecting the activation of intensification processes of the enterprise include the market factors (intensification of competition, changes in consumers demand, a sharp increase in market supply, new trends in the labour market, unsatisfied customers and/or shareholders and their wishes) and the economic and administrative factors (strengthening of the state regulation liberalization, changes in taxation legislation, increased importance of environmental protection, etc.) $[2,3]$.
Taking into account the principle of hierarchy of intensification processes, it can be assumed that the most optimal level of intensification activation can be achieved while maintaining certain proportions between these processes. In similar way to the well-known "golden rule of the economics" [4], one can define the "golden rule of intensification" for the mechanical engineering enterprises, which shows that the dynamics of the intensification processes indicators must satisfy the following condition:

$$
I U R>I P P>I A>I D>1,
$$

where IUR, IPP, IA, ID are a race of change for the quantitative estimates of the intensification of the use of resources, production processes, activities, and development respectively.

A race of change for the quantitative estimates of the intensification processes is defined as a relationship between quantitative estimates for the current and previous periods. Obviously, one can speak about the activation of intensification processes and their positive dynamics only if a race of change of intensification processes in a current period is faster then a race of change of intensification processes in a previous period (Fig. 2).

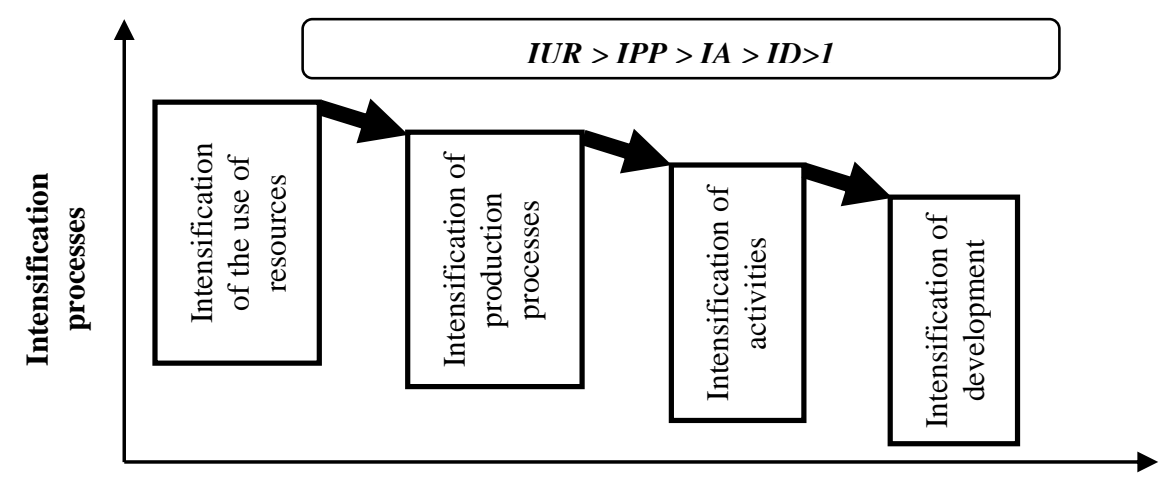

Fig. 2. The essence of the "golden rule of intensification" 
The essence of the "golden rule of intensification" is as follows:

- intensification of the use of resources, which serves as a basis for intensification of the production process, should have a higher race of change;

- intensification of a production process is the basis for the intensification of enterprise's activities as a higher level of the intensification hierarchy;

- intensification of activities creates the basis for the highest hierarchical level - intensification of development.

The "golden rule of intensification" characterizes the economic potential of the enterprise, its ability to develop. If the "golden rule" is executed in the ratio defined by the formula (1), then this is an evidence of the positive trends in the enterprise. If this condition is not met, then this is an indicator of a situation that there are some obvious or hidden negative or crisis factors. The "golden rule of intensification" contains a very rational aspect, since the indicators characterizing the intensification processes must be mutually agreed, interconnected, and mutually ordered in dynamics.

The "golden rule" is a certain economic model of enterprise development. Therefore, the comparison of actual indicators of the enterprise with this model allows to identify the dynamics of its development as stable if the ratio of indicators is maintained within the given limits and as unbalanced if the ratio is not satisfied. The imbal- ance of the "golden rule of intensification" may indicate deep structural imbalances of the mechanical engineering enterprises, the lack of stable development and the need to take effective measures to remedy the situation.

Therefore, the algorithm for application of the AIP concept should include the following main stages (Fig. 3):

Stage 1. To characterize the directions and factors for activation of intensification processes at each level of the intensification hierarchy, taking into account the specific conditions of a mechanical engineering enterprise.

Stage 2. To estimate the relationship between the indicators of intensification processes (determination of the quantitative value of the relationship between partial, complex, and integral indicators should be conducted using a correlation analysis).

Stage 3. To place the intensification processes by comparing their quantitative indicators (it is advisable to apply a matrix approach for choosing the direction to activate the use of resources, production processes, activities and development).

Stage 4. To verify how the "golden rule of intensification" is implemented. To identify and analyze ways to activate the intensification processes for a specific selection of the mechanical engineering enterprises. To identify the factors of the internal and external environment of the mechanical engineering enterprises, which slow down the activation processes.

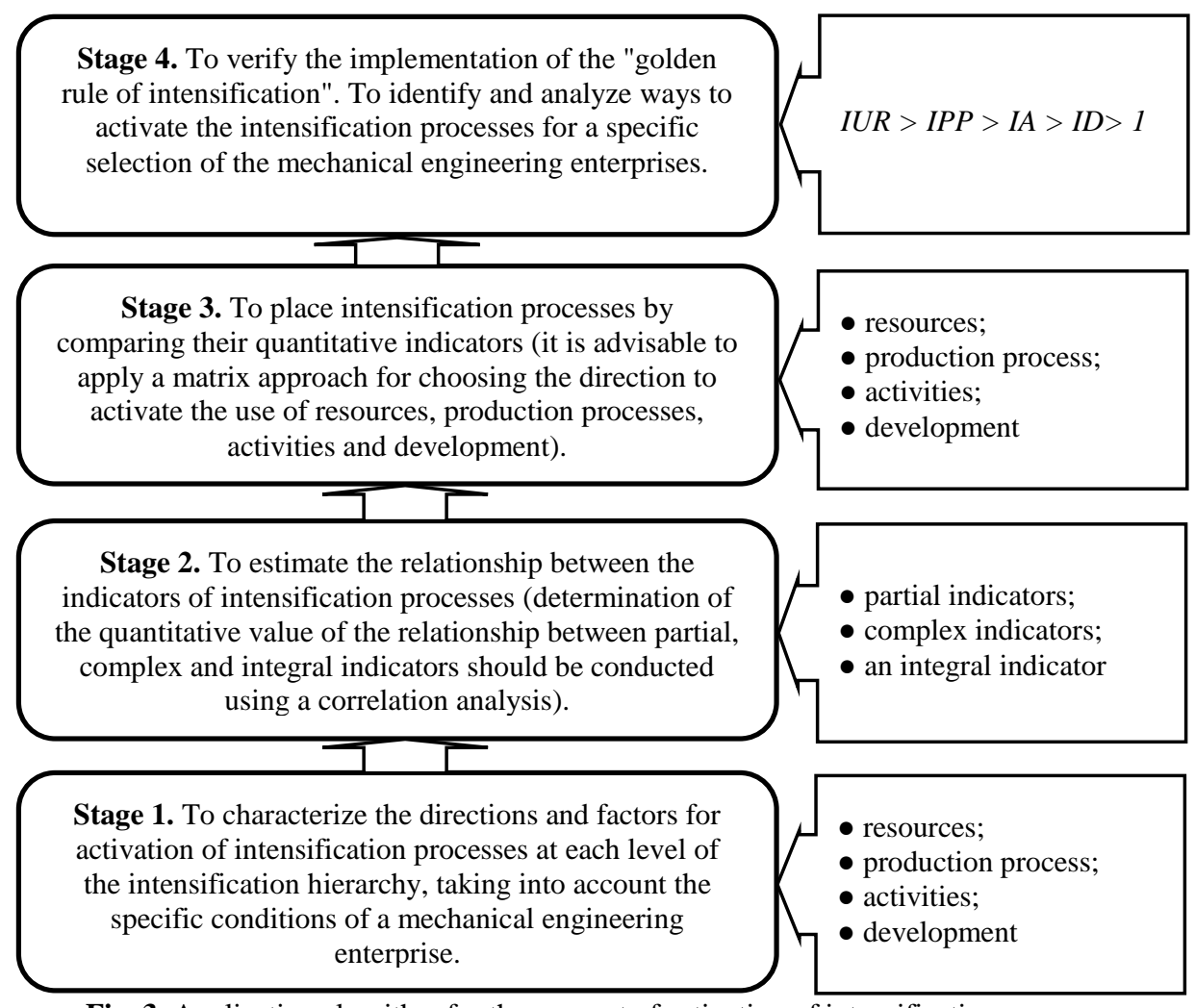

Fig. 3. Application algorithm for the concept of activation of intensification processes Source: developed by authors

Approbation of the proposed concept of activation of intensification processes allowed to reveal the main directions, implementation of which ensures satisfaction with the golden rule of intensification. Thus, the most important directions of intensification of the use of resources include: to rationalize the use of resources and to increase the resource efficiency; to introduce a system of economical use of resources; to purchase the high-performance machines and equipment, to retrofit the equipment, etc. 
Among the priority directions of intensification activation of the production process, it is expedient to highlight the following ones: resource and technological reproduction; implementation of resource saving technologies, economical production systems; increasing the intensive use of productive resources.

The directions for activation of the activities intensification of the mechanical engineering enterprises are: optimization of enterprise's activities; optimization of production costs; improvement of management processes and methods; improvement of sales policy (promotion of products to the market, interaction with consumers, organization of sales activities); activation of innovation activity.

The most important directions for activation of intensification processes of the economic entity are: intensification of the innovation and investment component within its activities, which is aimed at carrying out scientific and technological changes in the production and economic system, accompanied by technical re-equipment, new improvements; application of the cluster approach to the organization of production. Creating the innovation and production clusters of machinery type allows to combine resources and competences of different economic entities within the clusters, accelerates the process of import sub- stitution, gives a new impetus to scientific and technological development, increases the technological level of production, reduces the cost of production, creates favorable conditions for active implementation innovations.

Conclusions. The process of intensification is an objective and logical factor in development of the mechanical engineering enterprises and is typical for countries with market economies. In the conditions of instability, uncertainty, and dynamism of the economic environment, development and implementation of the concept of activation of intensification processes that have a hierarchical subordination are an adequate tool for implementing the set goals and objectives, namely: intensification of the use of resources - intensification of the production process intensification of activities - intensification of development. Interconsistency, interconnectedness, and orderliness of the levels of the hierarchy of intensification should be evaluated with the "golden rule of intensification". Each level of intensification processes requires identification of the effective factors and directions for their activation both within a separate enterprise and within the mechanical engineering sector as a whole. Determination of the stimulants and disintegrators of sustainable development of the enterprises is the main goal for implementing the AIP concept.

\section{REFERENCES}

1. Stanislavyk O. Actual ways and factors of domestic enterprise competitiveness increase підприємства [E. resource] / O. Stanislavyk, O. Kovalenko // Economic forum. - 2017. - № 2. - P. 223-231. - Mode of access: http://nbuv.gov.ua/UJRN/ecfor_2017_2_39.

2. Kovbatyuk M., Benyk N. The impact of internal and external environment on the process of operation and adaptation of enterprises [E. resource] / M. Kovbatyuk, N. Benyk // Water transport. - 2016. - Вип. 2. - P. 101-108. - Mode of access: Режим доступу: http://nbuv.gov.ua/UJRN/Vodt_2016_2_17.

3. Toffler A. The Adaptive Corporation. - Aldershot: Gower,1985. - $194 \mathrm{p}$.

4. Economic Analysis: Theory and Practice / G. I. Kindratska, M. S. Bilyk, A.G. Zagorodniy. - Lviv: Magnolia Plus, 2006. $428 \mathrm{p}$.

5. Innovative development of the enterprise. Training manual / [Mikitiuk P. P., Krysko J. L., Ovsyanyuk-Berdadina O. F. et al.]: Ed. P. P. Mikitiuk. - Ternopil: PP «Printer Inform», 2015 $-224 \mathrm{p}$.

\section{Активизация процессов интенсификации в машиностроении как фактор устойчивого развития предприятий} В. Н. Марченко, Н. Н. Покровская

Аннотация. В статье предложено интенсификацию производства рассматривать как совокупность процессов интенсификации, которые имеют иерархическую (логическую) подчиненность. Разработана структурная модель концепции активизации процессов интенсификации и алгоритм ее применения. Предложено «золотое правило интенсификации» машиностроительных предприятий и раскрыто его сущность.

Ключевые слова: интенсификачия, активизаџия процессов интенсификации, внутренняя среда, внешняя среда, золотое правило интенсификации. 